\title{
Research on Environmental Accounting Information Disclosure Problems
}

\author{
-A Case Study of Highly Polluted Industry in Shandong Province
}

\author{
Dong Lingling \\ Shandong Women's University \\ Jinan, Shandong 250300
}

\begin{abstract}
Since reform and opening up, environmental pollution problem caused by the high-speed economic development in our country has attracted the public's wide attention. Environmental accounting information disclosure problem in the accounting calculation system for enterprises has become an irresistible trend. This paper conducts an investigation and research on the environmental accounting information disclosure problems on the listed company in highly polluted industry in Shandong Province. Through the analysis of the content and method of the environmental accounting information disclosure, problems such as the informal disclosure form, incomplete and undergrad disclosure content, lacking of the comparability between firms and industries have been found. This paper has provided corresponding suggestions from the points of view of enterprises, government and the public. It is hoped that the disclosure situation of the listed company in highly polluted industry in our country can be improved.
\end{abstract}

Keywords-environmental accounting; information disclosure; highly polluted industry

\section{INTRODUCTION}

After reform and opening up, China's economy is steadily growing, which has aroused earthling attention. The following worsening of environment and environmental crisis has sound an alarm of protecting the environment in the whole society. As for the public, demanders of the outside information of the enterprises' accounting information, the only way to know the enterprises environmental behavior is the environmental accounting information disclosed by enterprises. The disclosure situation of the environmental accounting information in highly polluted industry has attracted the public's wide attention. Compared with the foreign environmental accounting information theory, the relative theory in our country starts relatively late. The integrated research of theory and practice has become an irresistible trend [1].

This paper takes the data of listed companies in highly polluted industry as the research object, through which the outside information demanders are able to know the real and comprehensive environmental information. Besides, it has provided some fixed reference for government and enterprises in order to help the relevant authorities to supervise the environmental behaviors caused by enterprise's business operations and standardize enterprise's behavior of ignoring the environmental pollution for pursuing profitability, through which the maximization of economic benefit and environmental benefit will be achieved. Thus the social resources will be reasonable optimized and allocated, and the economic sustainable development will be realized.

\section{ANALysis OF THE CURRENT Disclosure SituAtion of \\ ENVIRONMENTAL ACCOUNTING INFORMATION IN HIGHLY POLLUTED INDUSTRY IN SHANDONG PROVINCE}

Environmental accounting is also known as green accounting, which is an emerging sub discipline of accounting. Based on conventional accounting, it makes a correct estimate of economic, social and environmental benefits through the method of monetary measurement, which is effectively combined. It is an economy management work of acknowledgement, measurement and report [2]. Its aim is to build a resource-saving and environment-friendly society through the reasonable compensation to the consumed natural resources.

Highly polluted industry refers to those enterprises with operational activities which have led to the decreasing indices of environmental quality and caused damage to the survival and development of human being, animals and plants in the natural world [3]. As stipulated, the listed companies of this kind should disclose annual social responsibility report and information of environmental law observation, environmental management and periodic pollutant emission situation.

Environmental accounting information disclosure refers to the announcement which is made by enterprises to the information demanders about the financial information and nonfinancial information influenced by everyday environmental activities through corresponding medium measures. Therefore, the concept of environmental accounting information disclosure should be enterprises adopt the method of report, notion and environmental statement to reflect the environmental accounting information and present to public the behaviors and consequences related to environment in a way of monetary and non-monetary.

Shandong Province, as an economy-prosperous province in our country, possesses 72 listed companies in highly polluted industry. It is of great importance to pay attention to the environmental accounting information disclosure situation. Through the disclosure of the environmental accounting 
information in the report, the characteristics of the environmental accounting information disclosure in highly polluted industry of Shandong Province are discovered after investigation and summary:

\section{A. In Terms of the Content of Environmental Accounting Information Disclosure}

Due to various reasons, the quality level of various contents of environmental accounting information disclosed by enterprises is escalated. However, based on the analysis, some disclosure content with higher proportion is due to the mandatory provisions made by the government to a large extent. For example, there is no request of the annual report, environmental law observation and pollutant emission made by the environmental management authority. Therefore, in the report of the listed companies, the percentage of environmental accounting information disclosure is relatively low.

\section{B. In Terms of the Way of Environmental Accounting Information Disclosure}

There is no specific mode request in disclosure. Therefore, various ways can be chosen. Most of the enterprises mainly adopt annual report, social responsibility report (sustainability reporting) and network-medium to disclose. Currently, the way of environmental accounting information disclosure of the listed companies in highly polluted industry is annual repost, which accounts for more than $80 \%$. Besides, most of them are disclosed in the directors' report and notions. Few enterprises only make their brief disclosure in the important notice. The way of adopting work report of supervisory committee is fewer, which is not even been used by one enterprise in the last two years; nearly half of the enterprises choose to disclose in the social responsibility report. There are 31 enterprises used this way in the year of 2015 and 30 enterprises in the year of 2016; more than 18 enterprises choose the way of network-medium to disclose the environmental accounting information, which mainly lies in the convenience of internet development. Social masses can be directly acquainted with the environmental accounting information of enterprises within doors. There are various ways of disclosing the environmental accounting information, which do not have unified regulations.

\section{Problems Existed In The ENVIRONMENTAL ACCOUNTING INFORMATION DISCLOSURE OF THE LISTED COMPANIES IN \\ Highly POLLUTED INDUSTRY IN SHANDONG PROVINCE}

Through analyzing the current situation of the environmental accounting information disclosure of the listed companies in highly polluted industry in Shandong Province, this paper has discovered that the increasing number of enterprises have begun to emphasize the environmental protection problems. However, there are still problems of environmental accounting information disclosure of the listed companies in highly polluted industry which need to be urgently solved.

\section{A. Disclosure forms are informal, which are lacking of unity}

Through the investigative statistics of the form of environmental accounting information disclosure of the listed companies in highly polluted industry in Shandong Province, this paper has discovered the disclosure in the non-monetary way of written description and environmental indicators is just because the industry imitation and the need of the policy. However, the way of written description and environmental indicators do not stipulate the specific disclosure content, and the distribution among different industries is not uniform; the percentage of disclosure in the way of monetary form in less, which only accounts for $13.89 \%$ of the sample companies. It illustrates that there is no national standards mode of the environmental accounting information disclosure of the listed companies in highly polluted industry. The distribution of environmental information disclosed by the enterprises with serious pollution has been rather dispersed, which is not modular. For users of accounting information, understanding the overall environmental situation of enterprises is of great difficulty. Therefore, setting the unified environmental information disclosure form in highly polluted industry is imperative.

\section{B. Disclosure content is incomplete, which is relatively single}

Through the analysis of the content of the environmental accounting information disclosure of the listed companies in highly polluted industry in Shandong Province, this paper has discovered the majority content disclosed by the highly polluted industry is the monetary information which is useless for the need of demanders of various information of enterprises, such as the sewage charge and green fees of enterprises. There are all inevitable items of environmental expenditure in routine business activities. Enterprises will avoid the disclosure or do not make the disclosure when it is related to their enterprise self-benefit or has a harmful influence on their environment protection image of enterprises [4]. Because it will have an impact on performing the trusted responsibility view of enterprises, which leads to a sharp rise of the economy in whole industry. And the environment ecology will be destroyed, and the realizing of sustainable economic will be influenced.

\section{The quality of disclosure information is poor, and the practicability is poor}

A comparative analysis is performed to discover that there is not a direct proportion relationship between the environmental accounting information quality and disclosure quantity. The disclosure quality does not meet the standards, and it is not helpful for the information users. Since the carrying out of the sustainable development concept by the government, more enterprises start to do the environmental accounting information disclosure, but the information disclosure result is not so desirable. Moreover, the information disclosed by the listed companies is relatively general and lacks of necessary analysis, which is mainly to respond to the needs of national policy instead of considering the interest of other stakeholders. Operators are different to make correct decisions which are benefit for the development of the company. Thus the environmental information is lacking of practicability. 


\section{The environmental information in different industries is} lacking of comparability

Since there is no definite criterion to define the environmental accounting information disclosure, highly polluted industry usually adopts the relatively informal disclosure form. Not stipulating the way, form, content of information disclosure brings the difficulty for the information collection. And if the financial report which is reflecting the environmental accounting information of the enterprises discloses the past transactions or matters, and does not provide the comparable information material for future, the environmental accounting information lacks of perspectiveness. If a rational prediction for the future is not made, information users are not able to compare the environmental financial report of the same company in different years, or even to compare that among different companies in same industry, which does not meet the quality requirement of the environmental accounting information- comparability.

\section{COUNTERMEASURES OF IMPROVING THE}

ENVIRONMENTAL ACCOUNTING INFORMATION DISCLOSURE OF THE LISTED COMPANIES IN HIGHLY POLLUTED INDUSTRY IN SHANDONG PROVINCE

\section{A. Countermeasures from enterprises}

1) Strengthening enterprises' awareness and ability of environmental accounting information disclosure

The listed companies in highly polluted industry should attach importance to the environmental accounting information disclosure. Enterprises' integral environmental awareness should be strengthened. The company management should clearly realize the importance of environmental protection to the continuative development of enterprises. The manager level, such as general manager should participate in some environmental knowledge training, whose environmental awareness of taking the consequences if the environment was destroyed should be strengthened. Companies may communicate with the excellent enterprises in same industry about the experience of environmental accounting information disclosure and strengthen the ability of disclosing the environmental accounting information.

2) Perfecting the management system of environmental information

Based on the survey, we have found that there are fewer enterprises with a sophisticated management system of environmental information among the investigation object, which is of particular importance to the highly polluted industry. Therefore, companies should set up the technical environmental management departments and cultivate the excellent environmental knowledge-based talents. Environmental Performance Indicators should be regarded as one important indicator of judging the performance of enterprises. Social responsibility should be implemented into each department, or even each employee. Enterprises may adopt the measure of the fine of ruining the environment to build a green enterprise with environmental protection as the main idea. Enterprises should be encouraged to build a complete environmental management system, and then meet the certification standards of IS environmental management system.

\section{B. Countermeasures from government}

1) Perfecting the environment accounting system and norm

In highly polluted industry, the norm of environmental information disclosure is mainly focused on corporate governance, pollutant emission and waste disposal. But it is only the management of intra-company control, which do not force the enterprises to do the publicity disclosure [5]. Therefore, government should perfect the environmental accounting norm according with the features of highly polluted industry and restrain the environmental information disclosure behaviors of enterprises. All industries may submit a joint letter to government and advocate government relevant department to perfect the relative norm of environmental information disclosure. Thus the information disclosure may bear the characteristic of unity and meet the requirement of information quality.

\section{2) Intensifying supervision}

The force and breadth of disclosing the environmental information should be intensified. Government's supervision has become an urgent problem. The department concerned should establish environmental inspection panel and pay a visit irregularly to the polluting factories. Securities and Futures Commission, environmental protection department and Ministry of Finance should undertake their responsibility and supervise the environmental information disclosure in highly polluted industry together.

\section{Social countermeasures}

\section{1) Setting up environmental auditing system}

Currently, the highly polluted industry has not build up the environmental accounting auditing system based on the survey. However, whether the environmental accounting information is valid or not, the verification should be done by the third-party audit authority. Our country should encourage adding the environmental auditing service based on the auditing of the financial accounting report and verify the authenticity and validity of the environmental auditing report submitted by auditors. The auditors cultivated by enterprises should work independently, who should not participate in any financial work in enterprises. Internal control system should be perfected.

2) Accelerating the research of environmental accounting theories and practices

The theoretical research of environmental accounting information disclosure in our country is still not studied fully [6]. In this situation, we should learn the experience related to environmental information disclosure from abroad, organize the technological talents to study abroad and perfect the environmental information theory as soon as possible; in terms of practice. Enterprises should cultivate knowledge-based talents with grasping the environment knowledge and organize the personnel concerned to communicate with and learn from the advanced enterprises where the environmental accounting is well used. Environmental accounting should be integrated 
into traditional financial accounting calculation, which may cause the two-way development of theory and practice.

3) Strengthening public's environmental awareness

Currently, the majority of the public own the environmental protection awareness. But those who really care about the enterprises' environmental information disclosure are less. The social propaganda has not achieved the bot results. Therefore, the society should promote the propaganda work of environmental protection, strengthen the awareness of environmental protection continuously and carry out the environmental protection exchange meeting. Only when the public really want to know the environmental accounting information and ask enterprises to disclose is can be the effective way to solve the problems of the current situation of the environmental accounting information disclosure.

\section{CONCLUSION}

Based on the survey and analysis of the current situation of the environmental accounting information disclosure of the listed companies in highly polluted industry in Shandong Province, this paper has analyzed the reasons of the appearance of the disclosure problems from the aspect of enterprises, government and society and provided rational countermeasures, with an aim of improving the situation of the environmental accounting information of listed companies in highly polluted industry which has been disclosed.

Through the investigation and analysis of the environmental accounting information disclosure of the listed companies in highly polluted industry in Shandong Province, there are mainly four problems existed: disclosure forms are informal, which are lacking of unity; disclosure content is incomplete, which is relatively single; the quality of disclosure information is poor, and the practicability is poor; the environmental information in different industries is lacking of comparability. In respect of the problems above, this paper has found the reasons in the aspect of enterprises, government and society and provided corresponding suggestions.

\section{REFERENCES}

[1] [1] Wang Ting. Research Progress on the Environmental Accounting Information Disclosure at Home and Abroad [J]. Chifeng University Journal, 2015, (12): 3-4. (In Chinese)

[2] [2] Ge Jiashu, Li Ruoshan. A New Idea of Western Accounting Theories in $1990 \mathrm{~s}$-Green Accounting Theory [J]. Accounting Research, 1992, (5): 15-17. (In Chinese)

[3] [3] Wang Yong. Research on the Environmental Accounting Information Disclosure-A Case Study of Shandong Sun Paper Industry Co., Ltd. [J]. Modern Property Management• Modern Economy, 2015, (04): 22-24. (In Chinese)

[4] [4] Yue Yan. The Analysis of the Environmental Accounting Information Disclosure in Highly Polluted Industry [J]. Friends of Accounting, 2015, (21): 16-18. (In Chinese)

[5] [5] Guo Lina. The Research on the Environmental Accounting Information Disclosure in Highly Polluted Industry [D]. Harbin University of Commerce, 2015, (06):10-19. (In Chinese)

[6] [6] Shi Dangying. The Research on the Environmental Accounting Information Disclosure of the Listed Companies in Shaanxi Province [J]. Commercial Accounting, 2016, (17): 19-21. (In Chinese) 